
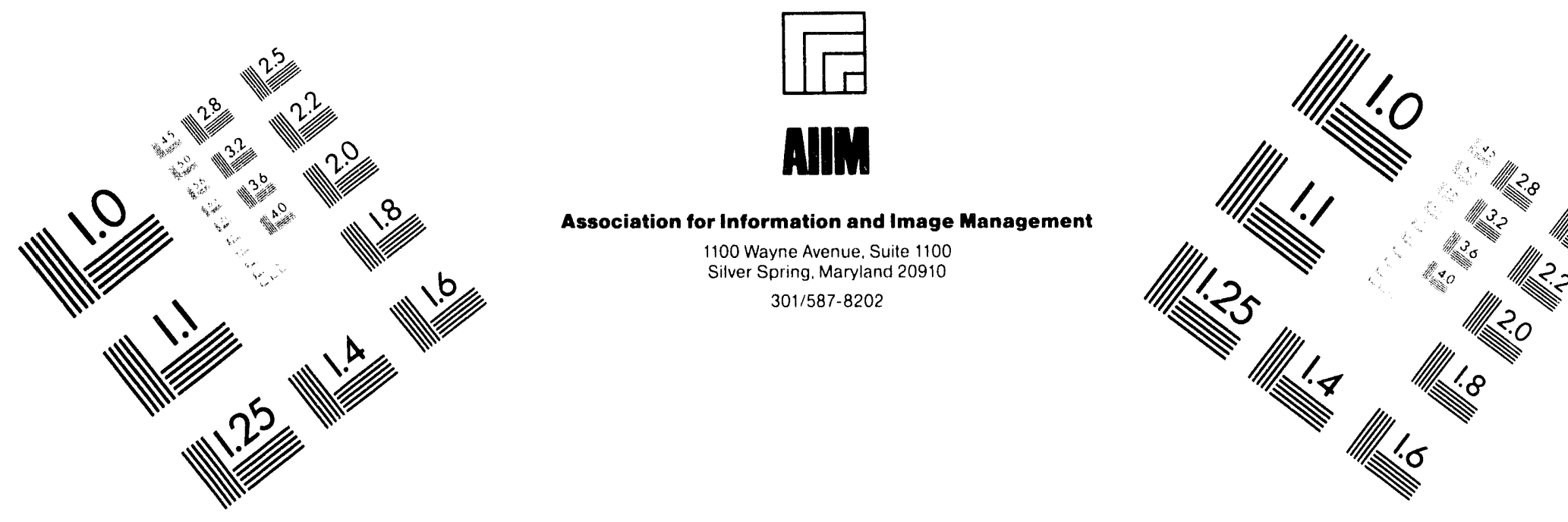

\title{
Centimeter
}

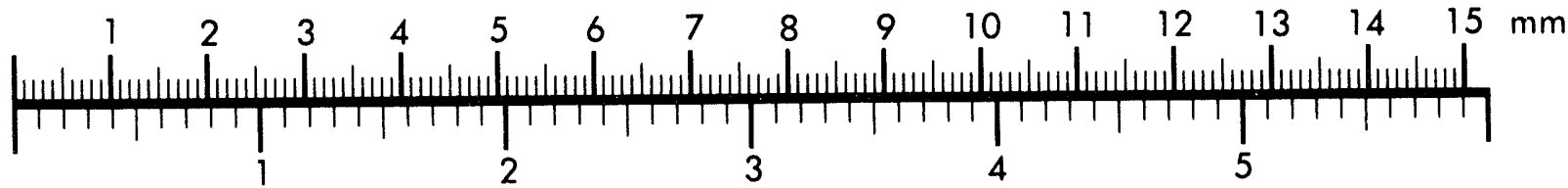

Inches
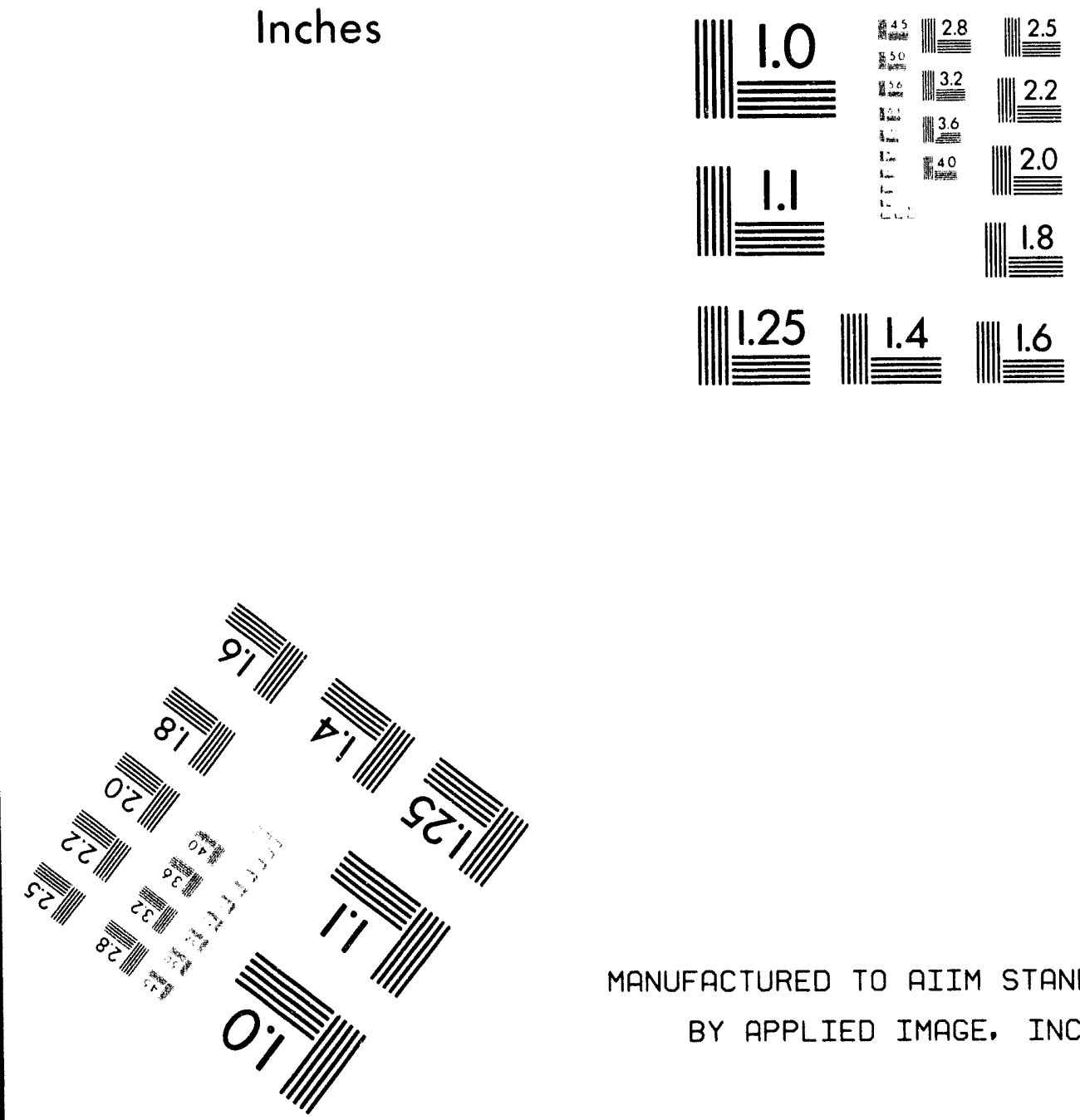

MANUFACTURED TO AIIM STANDARDS

BY APPLIED IMAGE. INC.

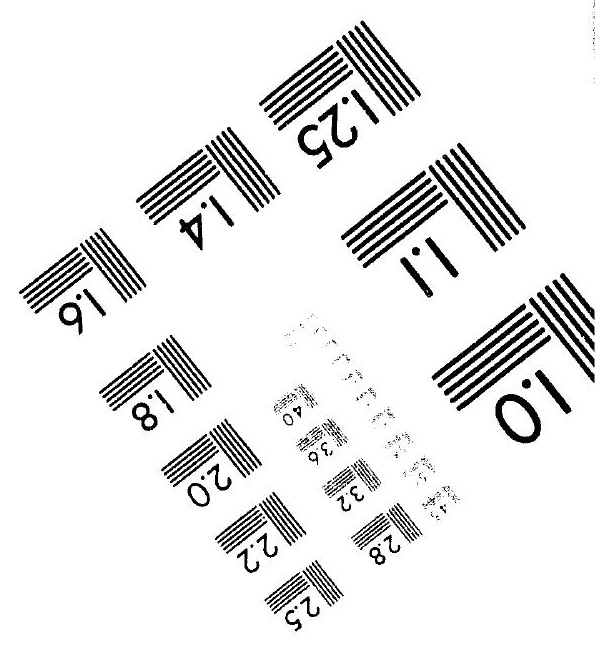



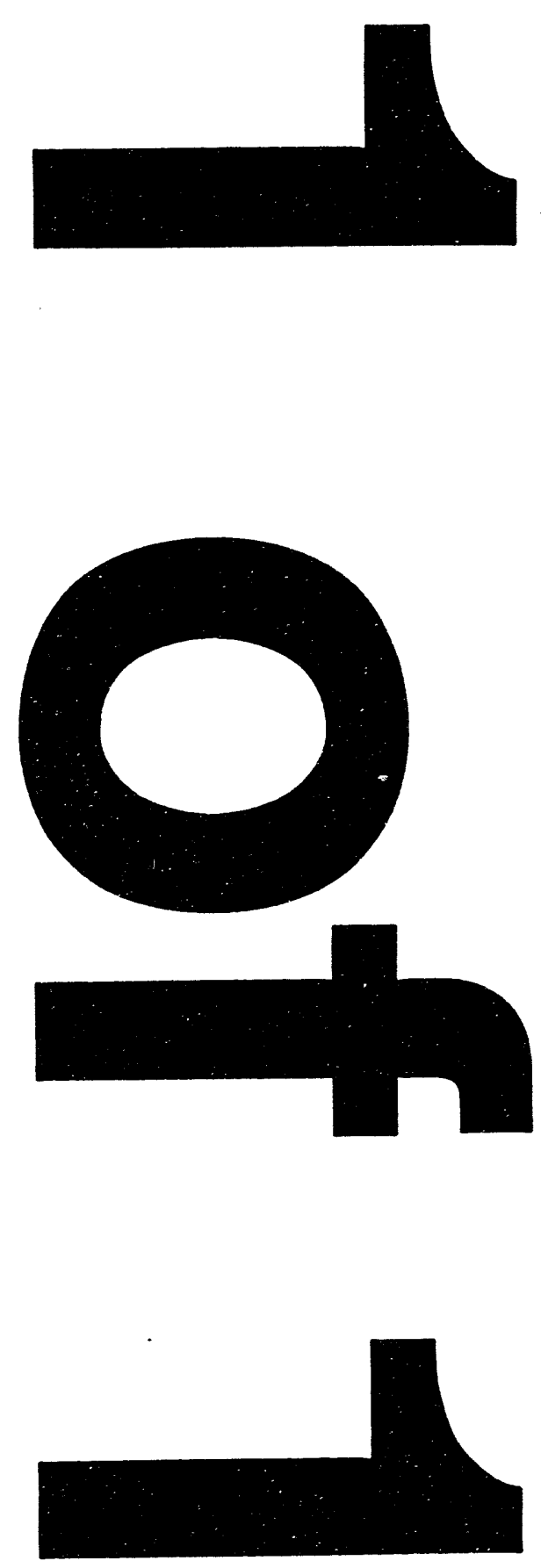


\section{QUARTERLY TECHNICAL PROGRESS REPORT FOR THE U.S. DEPARTMENT OF ENERGY}

Project Title:

Program:

Instrument No.:

Institution:

Date of Report:

Contract Date:

Anticipated Completion Date:

Government Award:

Project Director:

Principal Investigators:

UM Business Officer:

DoE Technical Project Officer:

Performance Period:

\section{NOVEL CATALYSTS FOR UPGRADING COAL-DERIVED LIQUIDS}

The U.S. Department of Energy, Pittsburgh Energy Technology Center, University Coal Research Core Program, Program Solicitation No. DE-PS22-92PC92520

DE-PS22-92PC92537

University of Michigan, Department of Chemical Engineering, Ann Arbor, MI 48109-2136

December 31, 1993

September 4, 1992

November 3, 1994

$\$ 188,720$

Prof. Levi T. Thompson

Prof. Levi T. Thompson

Prof. Phillip E. Savage

Prof. Dale E. Briggs

David Plawchan

Sally Kornfield

October 1, 1993 - December 31, 1993

\section{DISCLAIMER}

This report was prepared as an account of work sponsored by an agency of the United States Government. Neither the United States Government nor any agency thereof, nor any of their employees, makes any warranty, express or implied, or assumes any legal liability or responsibility for the accuracy, completeness, or usefulness of any information, apparatus, product, or process disclosed, or represents that its use would not infringe privately owned rights. Reference herein to any specific commercial product, process, or service by trade name, trademark, manufacturer, or otherwise does not necessarily constitute or imply its endorsement, recommendation, or favoring by the United States Government or any agency thereof. The views and opinions of authors expressed herein do not necessarily state or reflect those of the United States Government or any agency thereof.
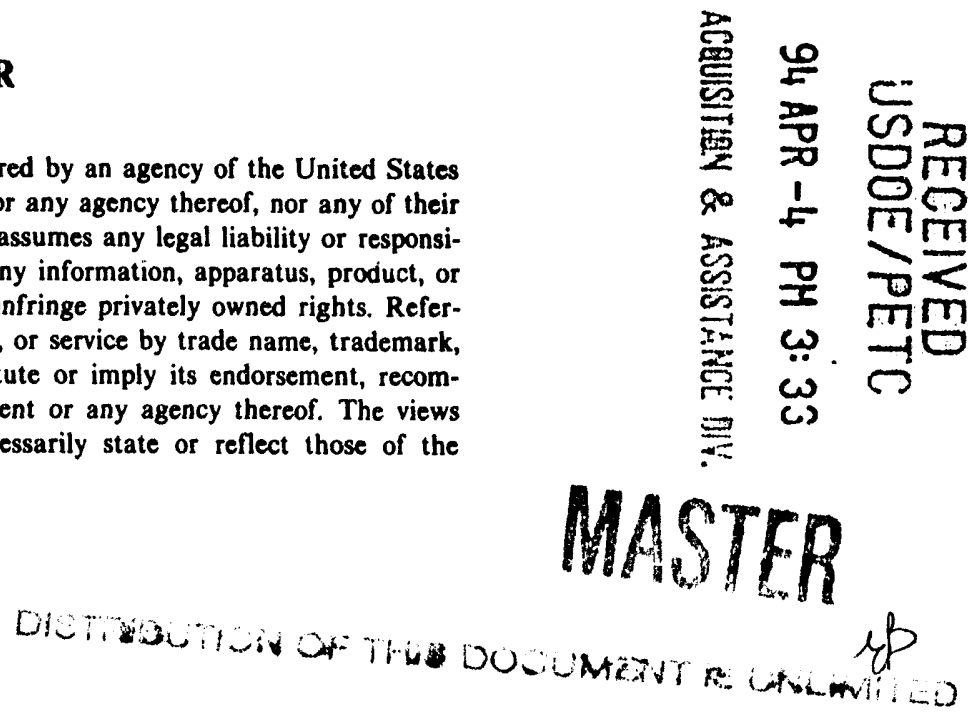


\section{Summary of Work Completed}

We evaluated the catalytic properties of a series of supported molybdenum nitride catalysts. These catalysts were prepared in our laboratory for comparison with the supported molybdenum oxynitrides. Pyridine hydrodenitrogenation (HDN) was used as the test reaction.

\section{Introduction}

Coal liquefaction and coal-oil co-processing are perhaps the most promising technologies for the conversion of coal into high-quality, clean-burning transportation fuels. An important step in the conversion process involves upgrading (e.g., heteroatom removal and hydrogenation) the coal-derived liquids. These liquids tend to be richer in heteroatoms, more aromatic and higher molecular weight than typical crude oils, and conventional petroleum hydrotreatment catalysts tend to be less effective for upgrading coal-derived liquids (Xu et al., 1991). Current coal liquefaction research and development efforts typically have taken one of two approaches to solving this problem (Derbyshire, 1989). The first is to develop improved coal dissolution catalysts that will lead to liquid products with characteristics more closely resembling that of petroleum crude oil. This approach, if successful, would facilitate the implementation of existing crude oil refining technology for the downstream processing of coal-derived liquids. The second approach, which is adopted in this research, recognizes that coal-derived liquids do differ from petroleum crude oils and aims to develop new catalysts specifically for the upgrading process. If effective, these catalysts could be integrated into existing coal liquefaction and co-processing technologies and significantly improve the economic feasibility of developing commercial processes for the conversion of coal into transportation fuels.

\section{Project Description}

The principal objective of this research is to evaluate the hydrotreatment properties of $\gamma$ $\mathrm{Al}_{2} \mathrm{O}_{3}$ supported Mo oxynitride and oxycarbide catalysts. This information will be used to assess the potential of these materials for use as commercial catalysts for hydrotreating coalderived liquids. Specific research objectives that will be accomplished include the:

1. Preparation of a series of $\gamma-\mathrm{Al}_{2} \mathrm{O}_{3}$ supported Mo oxynitride and oxycarbide catalysts. Novel synthesis strategies have been devised for this purpose. (We have also prepared and characterized Mo nitride and carbide catalysts for comparison with the oxynitrides and oxycarbides.)

2. Evaluation of their catalytic properties for the hydrodenitrogenation, hydrodesulfurization and hydrodeoxygenation of model reactants and authentic coal-derived liquids. This will include determining their activities, selectivities and reaction pathways.

3. Characterization of the sorption and bulk structural properties of the catalysts at various stages during their genesis and following the reaction studies. This will provide useful information for the development of structure-function relationships for Mo oxynitride and oxycarbide catalysts.

\section{Project Status}

\section{Experimental}

A series of alumina supported molybdates with nominal loadings of 4 and $8 \mathrm{wt} \%$ Mo were prepared using the incipient wetness method. A solution of ammonium heptamolybdate, 
$\left(\mathrm{NH}_{4}\right)_{6} \mathrm{Mo}_{7} \mathrm{O}_{24} \cdot 4 \mathrm{H}_{2} \mathrm{O}$ in deionized water was added dropwise to precalcined $(773 \mathrm{~K}, 5 \mathrm{~h}$, dry air) $\gamma-\mathrm{Al}_{2} \mathrm{O}_{3}\left(190 \mathrm{~m}^{2} / \mathrm{gr}\right)$. The materials were then calcined for $5 \mathrm{~h}$ at $773 \mathrm{~K}$ in dry air. Loadings beyond $\approx 10 \mathrm{wt} \%$ Mo could not be accomplished using this method, therefore equilibrium adsorption was used to prep?r? $\gamma-\mathrm{Al}_{2} \mathrm{O}_{3}$ supported molybdates with loadings of $16 \mathrm{wt} \% \mathrm{Mo}$. A $0.007 \mathrm{M}$ solution of $\left(\mathrm{NH}_{4}\right)_{6} \mathrm{Mo}_{7} \mathrm{O}_{24} \cdot 4 \mathrm{I}_{2} \mathrm{O}$ in deionized water was prepared and adjusted to $\mathrm{pH}=$ 1.1 using $\mathrm{HNO}_{3}$. Ten grams $(1 \mathrm{l} \mathrm{g})$ of $\gamma-\mathrm{Al}_{2} \mathrm{O}_{3}$ were then added to this solution and stirred for 96 $h$. The solution was filtered and the resulting cake was dried at $373 \mathrm{~K}$ for 60 minutes and then ground to a loose powder. Finally, the materials were calcined at $773 \mathrm{~K}$ for $5 \mathrm{~h}$ in dry air.

The supported molybdates were nitrided with $\mathrm{NH}_{3}$ using different molar hourly space velocities and heating rates (see Table 1). The temperature program consisted of four segments: rapid heating from room temperature to $623 \mathrm{~K}$ in $30 \mathrm{~min}$, heating from $623 \mathrm{~K}$ to $723 \mathrm{~K}$ at a rate $\left(\beta_{1}\right)$ of $40(-)$ or $100(+) \mathrm{K} / \mathrm{h}$, heating from $723 \mathrm{~K}$ to $973 \mathrm{~K}$ at a rate $\left(\beta_{2}\right)$ of $100(-)$ or $200(+) \mathrm{K} / \mathrm{h}$, and soaking at $973 \mathrm{~K}$ for $60 \mathrm{~min}$. The materials were cooled to room temperature in $\mathrm{NH}_{3}$ then passivated with $1 \% \mathrm{O}_{2}$ in $\mathrm{He}$ for $2 \mathrm{~h}$ to inhibit bulk reoxidation.

Table 1. Summary of the Conditions Used to Prepare the Supported Mo Nitrides

$\begin{array}{ccccc}\begin{array}{c}\text { Catalyst } \\ \text { Code }\end{array} & \begin{array}{c}\text { Molybdenum } \\ \text { Loading (wt\%) }\end{array} & \begin{array}{c}\text { Molar Hourly } \\ \text { Space Velocity } \\ (1 / \mathrm{hr})\end{array} & \begin{array}{c}\boldsymbol{\beta}_{1} \\ (\mathrm{~K} / \mathrm{h})\end{array} & \begin{array}{c}\boldsymbol{\beta}_{2} \\ (\mathrm{~K} / \mathrm{h})\end{array} \\ \text { T9N } & 4.2 & 17 & & \\ \text { T5N } & 4.2 & 17 & 100 & 200 \\ \text { T7N } & 4.2 & 8.5 & 40 & 200 \\ \text { T1N } & 8.4 & 17 & 100 & 200 \\ \text { T3N } & 8.4 & 17 & 100 & 200 \\ \text { T2N } & 8.3 & 8.5 & 40 & 200 \\ & & & 100 & 200 \\ \text { T18N } & 16 & 17 & 100 & 200 \\ \text { T19N } & 16 & 17 & 40 & 100 \\ \text { T20N } & 16 & 17 & 40 & \end{array}$

The pyridine HDN activities and selectivities were measured using a $6.35 \mathrm{~mm}$ OD Pyrex reactor. Approximately $0.2 \mathrm{~g}$ of catalyst were placed on top of a glass wool plug and heated to $673 \mathrm{~K}$ at $2 \mathrm{~K} / \mathrm{min}$ in flowing $\mathrm{H}_{2}$. The catalysts were held at $673 \mathrm{~K}$ for at least $12 \mathrm{~h}$ then cooled to the reaction temperature. Between measurements, the catalysts were held at $673 \mathrm{~K}$ for at least 12 $h$ in flowing $\mathrm{H}_{2}$. A stream of $\mathrm{H}_{2}$ flowing at $20 \mathrm{~cm}^{3} / \mathrm{min}$ was bubbled through a pool of anhydrous pyridine at $273 \mathrm{~K}$ and passed over the catalyst bed. The reactor effluent was analyzed using gas chromatography.

The catalytic properties of a commercial sulfided $\mathrm{Ni}-\mathrm{Mo} / \mathrm{Al}_{2} \mathrm{O}_{3}$ hydrotreatment catalyst (Crosfield $504-\mathrm{K}, 19 \% \mathrm{MoO}_{3}, 5.4 \% \mathrm{NiO}$, balance $\mathrm{Al}_{2} \mathrm{O}_{3}$ ) were also evaluated. First, the catalyst pellets were crushed and sieved to a $60 / 80 \mathrm{mesh}$. The catalyst was heated from room temperature to $673 \mathrm{~K}$ at $2 \mathrm{~K} / \mathrm{min}$ in $20 \mathrm{~cm}^{3} / \mathrm{min}$ of $\mathrm{H}_{2}$ then sulfided for $4 \mathrm{~h}$ at $673 \mathrm{~K}$ in a mixture of $2 \% \mathrm{H}_{2} \mathrm{~S}$ in $\mathrm{H}_{2}$ flowing at $20 \mathrm{~cm}^{3} / \mathrm{min}$. These conditions approximate those typically used to pretreat commercial hydrotreating catalysts. Prior to the activity measurements the catalyst was reduced at $673 \mathrm{~K}$ for at least $12 \mathrm{~h}$ in $\mathrm{H}_{2}\left(20 \mathrm{~cm}^{3} / \mathrm{min}\right)$.

$\underline{\text { Results }}$

The pyridine $\mathrm{HDN}$ reaction rates for the supported molybdenum nitride catalysts and a sulfided $\mathrm{Ni}-\mathrm{Mo} / \mathrm{Al}_{2} \mathrm{O}_{3}$ in Table 2. By every measure the supported nitrides were more active than the sulfided $\mathrm{Ni}-\mathrm{Mo} / \mathrm{Al}_{2} \mathrm{O}_{3}$ catalyst and of similar activity as unsupported molybdenum 
nitride. Note that the activities on a total Mo basis paralleled those on an oxygen uptake basis. In comparing the supported Mo nitride catalysts prepared using the same nitriding conditions, the activities of the $4 \%$ catalysis were higher than those of the higher loaded catalysts.

Table 2. Pyridine Hydrodenitrogenation Results

$\begin{array}{ccccc}\begin{array}{c}\text { Catalyst } \\ \text { Code }\end{array} & \begin{array}{c}\text { Reaction Rate } \\ \left(\mathrm{nmol} / \mathrm{g}_{\text {cat }} / \mathrm{s}\right)\end{array} & \begin{array}{c}\text { Activity }^{*} \\ (\mu \mathrm{mol} / \mathrm{mol} \mathrm{Mo} / \mathrm{s})\end{array} & \begin{array}{c}\text { Activity }{ }^{* \dagger} \\ \left(\mu \mathrm{mol} / \mathrm{mol} \mathrm{O}_{2} / \mathrm{s}\right)\end{array} & \begin{array}{c}\Delta \mathrm{E}_{\mathrm{a}} \\ (\mathrm{kcal} / \mathrm{mol})\end{array} \\ \text { T9N } & 7.6 & 18 & 430 & 28 \\ \text { T5N } & 9.2 & 22 & 640 & 23 \\ \text { T7N } & 6.0 & 14 & 500 & 32 \\ \text { T1N } & 4.0 & 4.8 & 100 & 23 \\ \text { T3N } & 7.8 & 9.4 & 490 & 16 \\ \text { T2N } & 3.9 & 4.7 & 190 & 21 \\ \text { T18N } & 14 & 8.4 & 260 & 25 \\ \text { T19N } & 14 & 8.4 & 180 & 20 \\ \text { T20N } & 9.7 & 5.8 & 91 & 25 \\ \text { bulk } \gamma \text {-Mo }{ }_{2} \mathrm{~N} & 47 & 4.8 & 360 & \\ \text { Ni-Mo/Al }{ }_{2} \mathrm{O}_{3} & 0.3 & 0.2 & 1.8 & \\ * \\ \text { measured at } 101 \mathrm{kPa} \text { and 633 K. }\end{array}$

The nitriding conditions had subtle affects on the activity. For the 4 and $8 \%$ Mo loaded catalysts, increasing the space velocity or first heating rate caused a decrease in the activity. For the $16 \%$ catalysts, an increase in the first or second heating rate caused an increase in the activity. All of the catalysts favored the production of alkanes with pentane being the predominant product.

Trends with respect to pyridine HDN were similar to those observed for quinoline HDN (see Table 3). In general the activity increased with increasing loading. Again the activities of the supported nitrides were higher than that for the commercial catalyst.

Table 3. Quinoline Hydrodenitrogenation Results

\begin{tabular}{|c|c|c|c|}
\hline Catalyst & $\begin{array}{l}\text { Loading } \\
\text { (wt\% Mo) }\end{array}$ & $\begin{array}{l}\text { Reaction Rate } \\
\left(\mathrm{nmol} / \mathrm{g}_{\mathrm{cal}} / \mathrm{s}\right)\end{array}$ & $\begin{array}{c}\text { Activity } \\
(\mu \mathrm{mol} / \mathrm{mol} \mathrm{Mo} / \mathrm{s})\end{array}$ \\
\hline $\begin{array}{l}\text { T9N } \\
\text { T7N }\end{array}$ & $\begin{array}{l}4.2 \\
4.2\end{array}$ & $\begin{array}{c}47 \\
352\end{array}$ & $\begin{array}{l}106 \\
804\end{array}$ \\
\hline $\begin{array}{l}\text { T1N } \\
\text { T3N } \\
\text { T2N }\end{array}$ & $\begin{array}{l}8.4 \\
8.3 \\
8.3\end{array}$ & $\begin{array}{c}39 \\
47 \\
179\end{array}$ & $\begin{array}{c}45 \\
54 \\
204\end{array}$ \\
\hline $\begin{array}{l}\text { T18N } \\
\text { T19N }\end{array}$ & $\begin{array}{l}16.0 \\
16.0\end{array}$ & $\begin{array}{l}120 \\
169\end{array}$ & $\begin{array}{c}72 \\
247\end{array}$ \\
\hline$-\mathrm{Mo} / \mathrm{Al}_{2} \mathrm{O}_{3}$ & 12.66 & 193 & 147 \\
\hline
\end{tabular}




\section{Planned Activities}

We plan to complete the synthesis of the oxycarbide catalysts and evaluate the catalytic properties of a series of molybdenum carbides.

\section{References}

Derbyshire, F., Energy and Fuels 3, 273 (1989).

Glemser, O. and Lutz, G., Z. Anorg. Allg. Chem. 264, 17 (1951).

Jaggers, C.H., Michaels, J.N. and Stacy, A.M., Chem. Mater. 2, 150 (1990).

Xu, L, Keogh, R.A. and Huang, C., ACS Div. Fuel Chem. Prep. 36, 1909 (1991). 

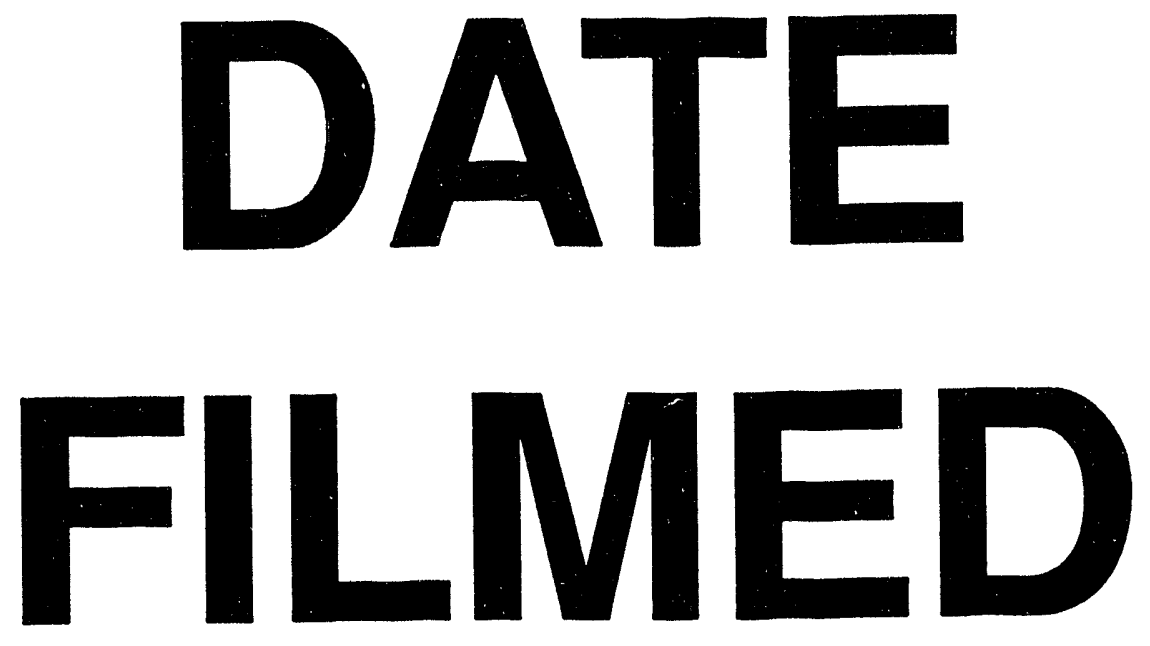

$6 / 22 / 94$
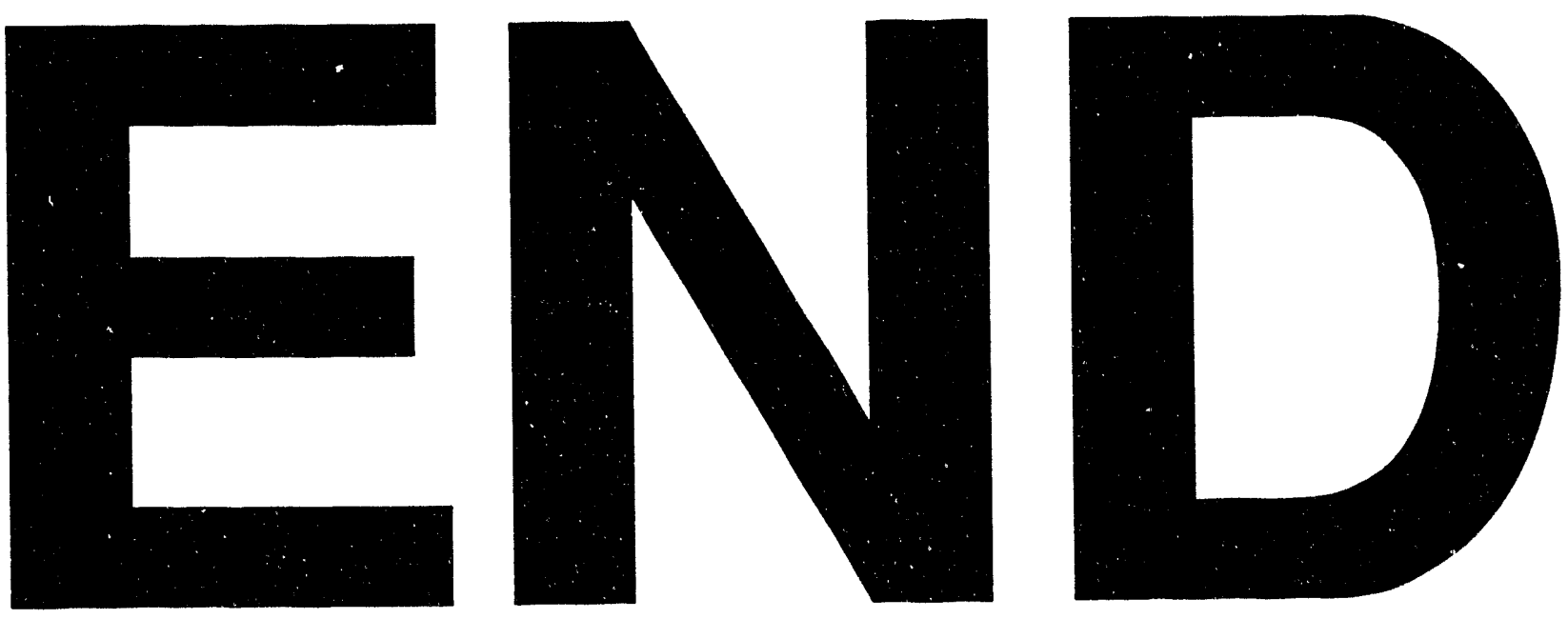
